\title{
Variations in the level of resistance to root-knot nematodes (Meloidogyne spp.) infestation among ten cowpeas (Vigna unguiculata L. Walp.) genotypes
}

\author{
F. KANKAM*, E. N. K. SOWLEY, J. ADOMAKO \& A. BOATENG \\ (F.K, E.N.K.S. \& A.B.: Department of Agronomy, Faculty of Agriculture, University for \\ Development Studies, P.O. Box TL 1882, Tamale, Ghana; J. A.: CSIR-Crops Research \\ Institute, Plant Health Division, P. O. Box: 3785, Kumasi, Ghana) \\ *Corresponding author's e-mail: fkankam@uds.edu.gh
}

\begin{abstract}
The cultivation of cowpea (Vigna unguiculata L. Walp.) cultivars that are tolerant to rootknot nematode attack is among the environmentally safe approach to managing the root-knot nematode menace in cultivated crops. In this study, the tolerance of 10 cowpea genotypes to root-knot nematodes infestation was evaluated in a pot experiment conducted in a Screenhouse, at the University for Development Studies, Nyankpala Campus. The experiment was laid out in a completely randomized design with three replications. The number of second stage juveniles (J2) per $250 \mathrm{~cm}^{3}$ of soil sample were counted while the severity of root-knot nematode damage (root galls) was assessed. The reproduction index (RI) was used to classify the varieties as resistant or susceptible. There was a significant difference $(P<0.05)$ in the number of second stage juveniles of root-knot nematode (RKN), galling index and RI among the genotypes tested. The study revealed that cowpea genotypes SARI 1-4-90, Padi tuya, Songotra, IT99K-1122, Sanzi and Apagbaala were moderately resistant whereas cowpea genotypes IT86D-610, Zaayura, SARI 5-5-5 and IT07K-299-6 were slightly resistant. Thus, the six moderately resistant cowpea genotypes were suggested to be used as a source of resistance to RKN in future breeding works.
\end{abstract}

Keywords: Root-knot nematode; root gall; tolerant; susceptible; resistant; cowpea genotypes. Original scientific paper. Received 22 Nov 18; revised 26 Jun 19

\section{Introduction}

Cowpea (Vigna Unguiculata L. Walp) is a popular and nutritionally important grain legume crop (Singh et al., 2014) and it is now widely cultivated throughout the tropics and subtropics. Sub-Saharan Africa accounted for about $70 \%$ of total world production of 1.56 million tons with West Africa representing the largest production zone (Gbaguidi et al., 2013). Grain yield varies with variety and the method of field pest control. An average yield of 1.5 t/ha is obtainable on farmers' field (Sokoto \& Singh, 2008), whereas between 1.8 and $2.5 \mathrm{t} /$ ha has been obtained on researchers plot (AduDapaah et al., 2005). Cowpea grain contains an average of $23-25 \%$ protein and $50-67 \%$ carbohydrate (Singh et al., 2014). Agbogidi and Egho (2012) emphasized that all parts of the plant used as food are nutritious providing proteins and minerals, immature pods and seeds are used as vegetables while several snacks and main dishes are prepared from the grains

Ghana Jnl Agric. Sci. 54 (2), 68 - 78

GJAS is an Open Access Journal and distributed under the terms of the Creative Commons (CC) License [CC BY 4.0] 
Apart from its culinary purpose, cowpea also provides ground cover that suppresses weeds in sole and intercropped plots and offer protection against soil erosion (Lawson et al., 2006). Farmers usually do not apply fertilizers to their cowpea fields because of its ability to fix atmospheric nitrogen through symbiotic relationship with nodule bacteria, although it has been reported that cowpea responds significantly to fertilizers including poultry manure and inorganic fertilizers (AgyenimBoateng et al., 2006; Sokoto \& Singh, 2008).

In the tropics and subtropics, the crop losses due to nematodes are $14.6 \%$ compared to $8.8 \%$ in temperate regions (Nicol et al., 2011; Surendra et al., 2014). Plant parasitic nematodes such as the root-knot nematodes reduce yield and quality of agricultural products consequently causing economic losses to the agricultural industry. Globally losses associated with root-knot nematodes is estimated at $\$ 157$ billion dollars annually (Singh et al., 2015). These pests cause damage by establishing a parasitic relationship with their host plants thereby transforming vascular cells into giant / or multinucleate feeding from which they exploit nutrients and water (Gheysen \& Mitchum, 2011). There are over 90 characterized species of economic importance in the Meloidogyne species (Lamovšek et al., 2013) and these are obligate endoparasites that are capable of infecting nearly every species of higher plants in a wide range of geographical distribution (Adegbite, 2011; Favery et al., 2016). There are three major Meloidogyne spp. that are common in the tropics namely; M. incognita, M. javanica and $M$. arenaria of which $M$. incognita is the most destructive among the species causing yield losses of up to 16\% (Moens et al., 2009).

Currently, synthetic nematicides used for the control of root-knot nematodes are being phased out due to their high toxicity (Lamovšek et al., 2013), on humans, livestock and environment hence the need to invest in safer agricultural practices for management of root-knot nematodes (Collange et al., 2011). Alternative to synthetic nematicides is the identification and incorporation of resistant crops in the farming cycle as cover or rotational crops to manage population buildup of the pest. Although some cowpea varieties have been reported to be tolerant against root-knot nematodes, there is the need to continuously screen other genotypes for their reaction to the pest. In view of this, ten improved cowpea genotypes developed by the CSIR-SARI were screened in the current study to determine their resistance level to a mixed population of rootknot nematodes.

The objective of this study was to identify the susceptibility and resistance of 10 cowpea genotypes to root-knot nematodes.

\section{Materials and methods}

Study site

The experiment was conducted at the Screenhouse of the University for Development Studies, Nyankpala Campus ( $9^{\circ} 42^{\prime} \mathrm{N}$ latitude and $0^{\circ} 92^{\prime} \mathrm{W}$ longitude and $184 \mathrm{~m}$ altitude) in the Tolon District of Northern Ghana within the Guinea Savannah Zone.

\section{Soil sample}

Well-drained fertile soil from the top soil containing a good mixture (sandy loam) was collected from the Plant House of the University for Development Studies, Nyankpala Campus.

\section{Sterilization of soil}

The soil was sterilized by steam using a steel barrel sterilization at the Screenhouse. The steam was filled with soil and well covered to prevent steam from escaping. The steam 
sterilizer has two chambers, the lower chamber containing water and the upper chamber filled with soil in a jute sack. Heat was supplied from pieces of firewood under steam sterilizer supported by three metal stands for three hours. When temperature of $103^{\circ} \mathrm{C}$ was obtained at the top layer of the soil and maintained for two hours the soil was considered well sterilized and allowed to remain on the fire for approximately 24 hours. Four steam-sterilizers were used and each had a capacity of approximately 150 litres that was filled with soil. Improvised Whitehead and Hemmings (1965) method were used to verify the effectiveness of the sterilization of the soil.

\section{Source of seeds}

The seeds used for the experiment were obtained from the Council for Scientific and Industrial Research (CSIR) - Savanna Agricultural Research Institute (SARI). The 10 cowpea genotypes include; IT86D-610, SARI1-4-90, "Padi tuya", "Zaayura", SARI-5-55, "Songotra", "Apaagbala", IT99K-1122, "Sanzi" and IT07-299-6.

\section{Sowing}

Sowing was carried out in plastic pots of $18 \mathrm{~cm}$ in diameter of which $5 \mathrm{~kg}$ of sterilized soil was added. Two seeds per hole of each of the 10 cowpea genotypes were sown at the depth of 2 $\mathrm{cm}$ in each pot.

\section{Experimental design}

The experimental design was completely randomized design with ten treatments replicated three times. The 10 treatments include; IT86D-610, SARI-1-4-90, "Padi tuya, "Zaayura", SARI-5-5-5, "Songotra", IT99K-1122, IT07-299-6, "Apagbaala" and "Sanzi". Apagbaala was released by the CSIR-
SARI years back while "Sanzi is the locally adopted type and was used as control against the other genotypes though no published evidence of previous RKN tests of "Apagbaala" and "Sanzi" could be found. In all, there were 30 experimental units.

Extraction of root-knot nematode second stage juveniles in root

Root-knot nematode second stage juveniles (J2) were extracted from root-knot nematodes infested tomato roots as described by Hussey \& Barker (1973). Briefly, $100 \mathrm{~g}$ of macerated tomato roots were placed in a wash bottle before adding $100 \mathrm{ml}$ of $0.5 \%$ sodium hypochlorite $(\mathrm{NaOCl})$ solution to cover the macerated roots. The wash bottle was then shaken vigorously for $5 \mathrm{~min}$ before pouring the mixture into 500 and $200 \mu \mathrm{m}$ mesh sieves which were nested. The sieves were then rinsed with slowly running tap water. The J2 were collected from the $500 \mu \mathrm{m}$ sieve into a clean beaker and covered.

Counting of second stage juveniles (J2)

The number of second stage juveniles (J2) in aqueous suspension was determined by the use of Doncaster counting tray. The suspension with the $\mathrm{J} 2$ was stirred continually whilst a pipette was carefully used to draw $5 \mathrm{ml}$ of the concentrated nematodes suspension in order to determine the number of $\mathrm{J} 2$ per unit volume of the suspension. The $5 \mathrm{ml}$ solution was then poured into a Doncaster counting tray and stirred slightly to ensure the nematodes spread evenly in the tray dish. This was also to ensure the uniform distribution of the $\mathrm{J} 2$ in the dish. Second stage juveniles (J2) in the channels were counted under a dissecting microscope of magnification x100 using a tally counter. After counting, the $\mathrm{J} 2$ suspension in the counting tray was poured back into the beaker and stirred to 
ensure uniform distribution of $\mathrm{J} 2$. The counting process was repeated three times and the average was taken. The $\mathrm{J} 2$ density of the $200 \mathrm{ml}$ suspension was estimated (Table 1). Therefore, the inoculum level was $1000 \mathrm{~J} 2 /$ pot. Thus, $1000 \mathrm{~J} 2 /$ pot served as the initial population of root knot nematodes for the current study.

TABLE 1

Estimation of root-knot nematode second stage juveniles (J2)

\begin{tabular}{ll}
\hline Count $(5 \mathrm{ml})$ & $\begin{array}{l}\text { Second stage juvenile } \\
\text { population }\end{array}$ \\
\hline 1 & 920 \\
2 & 1010 \\
3 & 1070 \\
Total J2 population & 3000 \\
$\begin{array}{l}\text { Average number } \\
\text { of J2 }\end{array}$ & 1000 \\
\hline
\end{tabular}

\section{Inoculation}

A population of approximately $1000 \mathrm{~J} 2 /$ pot was inoculated two weeks after sowing. The nematodes were inoculated via the $5 \mathrm{ml}$ syringe. The plants were watered a day before inoculation. A hole of about $3 \mathrm{~cm}$ deep was made near the base of the plant in the pot and inoculated with $5 \mathrm{ml}$ of $\mathrm{J} 2$ suspension containing approximately $1000 \mathrm{~J} 2 /$ pot. The pots with the plants were irrigated regularly to ensure growth and development of the plants.

\section{Data collected}

\section{Plant height}

The plant height was measured $(\mathrm{cm})$ from the base of the plant to the tip using meter rule at four, six and eight weeks after planting. This was done for each replicate.

\section{Number of leaves}

Leaf canopy spread in any crop to a very large extent determines its ability to absorb enough sunlight for photosynthesis, which invariably determines the number of carbons stored for plant use. The number of leaves for each of the ten tagged plants from each plot were therefore counted and recorded over a period of four weeks starting from the fourth week through to the eighth week as was done in the case of the plant height. Counting, as usual, was manually carried out by close observation.

\section{Number of pods per plant}

At the time of maturity when the plants have stopped flowering and the pods started drying, number of pods were counted on each plant. This was estimated by counting the number of pods from the five tagged plants harvested from the two middle rows and the mean recorded.

\section{Number of seeds per pod}

At maturity, the number of seeds per each pod was counted and the average was recorded. This was done for each replicate.

\section{Final nematodes assessment}

Two days to uprooting the plants, the soil around each plant was collected from the top to a depth of $3 \mathrm{~cm}$ using tablespoon. The uprooted roots each were washed thoroughly using a slow running tap water. Harvested plants were rated visually for the number of galls using a 0-5 galling index as follows. Each root of the plant was taken and the number of root galls were counted and scaled into root gall index. The root galling index was done as described by Taylor and Sasser (1978); scale of 0-5 (0 $=$ no galls, $1=1-2$ galls, $2=3-10$ galls, $3=$ 11-30 galls, $4=31-100$ galls, $5=$ more than 100 galls). Resistance and susceptibility of 
cowpea varieties were based on reproduction index (RI) which was calculated as the final nematodes eggs/juveniles extracted divided by the initial eggs/juveniles inoculated multiplied by 100 (Taylor, 1967). Reproduction index rating was as follows, $\mathrm{RI}=0$, (immune), $\mathrm{RI}<1$ (highly resistant), $1 \leq \mathrm{RI}<10$ (very resistant), $10 \leq \mathrm{RI}<25$ (moderately resistant), $25 \leq \mathrm{RI}$ $<50$ (slightly resistant), RI $>50$ (susceptible).

\section{Root nodules}

The roots of each plant were uprooted. The uprooted roots each were washed thoroughly using a slow running tap water. Each root of the plant was taken and number of root nodules formed were counted.

Root-knot nematode population per $250 \mathrm{~cm}^{3}$ of soil sample

From each of the $250 \mathrm{~cm}^{3}$ soil samples, rootknot nematode (RKN) eggs were extracted from the soil using the modified Baermann tray (Whitehead \& Hemming, 1965) method. RKN eggs were counted under a dissecting microscope.

\section{Statistical analysis}

All data collected were subjected to analysis of variance (ANOVA). Genstat ( $18^{\text {th }}$ edition) statistical package was used. Means were separated using least significant differences (LSD) at $5 \%$ probability level.

\section{Plant height}

From Table 2, significant difference $(P<0.05)$ existed among treatments for plant height at different growth stages. At 4WAP, there was significant difference between treatment SARI 5-5-5 and treatment Sanzi whereas there was no significant difference among the rest of the treatments. At 6WAP and 8WAP, significant difference existed between treatments SARI 5-5-5 and Zaayura but there existed no significant differences among the rests of the treatments.

TABLE 2

Mean cowpea plant height (cm) at different growth stages

\begin{tabular}{lccc}
\hline Treatments & 4 WAP & 6 WAP & 8 WAP \\
\hline IT86D-610 & 16.90 & 16.20 & 17.00 \\
SARI 1-4-90 & 19.70 & 20.40 & 21.70 \\
Padi tuya & 19.73 & 20.20 & 20.70 \\
Zaayura & 17.20 & 9.90 & 9.90 \\
SARI 5-5-5 & 21.77 & 22.40 & 23.30 \\
Songotra & 18.43 & 20.70 & 22.90 \\
IT99K-1122 & 16.20 & 15.30 & 18.90 \\
Sanzi & 14.37 & 13.40 & 12.60 \\
IT07K-299-6 & 16.63 & 17.60 & 20.40 \\
Apagbaala & 15.50 & 14.60 & 18.20 \\
LSD (0.05) & 7.167 & 11.13 & 12.32 \\
CV (\%) & 23.90 & 38.30 & 38.90 \\
\hline
\end{tabular}

Number of leaves

At 4WAP, significant difference $(P<0.05)$ existed among treatments IT86D-610, Sanzi and the control (Table 3). At 6WAP, there was significant difference between treatments Zaayura and the control. Also treatments IT86D-610, Padi tuya and Sanzi were significantly different from each other. There was no significant difference among treatments at 8 WAP. 
TABLE 3

Number of leaves of cowpea at different growth stages

\begin{tabular}{lccc}
\hline Treatments & 4 WAP & 6 WAP & 8 WAP \\
\hline IT86D-610 & 6.33 & 6.30 & 9.70 \\
SARI 1-4-90 & 9.33 & 9.00 & 10.70 \\
Padi tuya & 8.33 & 8.70 & 10.00 \\
Zaayura & 5.67 & 3.00 & 4.30 \\
SARI 5-5-5 & 9.00 & 11.30 & 14.00 \\
Songotra & 8.00 & 13.70 & 19.70 \\
IT99K-1122 & 13.33 & 14.70 & 12.30 \\
Sanzi & 6.00 & 7.30 & 10.30 \\
IT07K-299-6 & 7.00 & 11.30 & 18.70 \\
Apagbaala & 20.33 & 21.70 & 17.70 \\
LSD (0.05) & 6.441 & 12.80 & 15.64 \\
CV (\%) & 40.50 & 70.20 & 72.40 \\
\hline
\end{tabular}

Number of pods per plant and number of seeds per pod

Cowpea genotype (SARI 5-5-5) recorded the highest number of pods counted compared to cowpea genotype (ZAAYURA) recording the least number of pods formed (Table 3). Treatments SARI 5-5-5 and the control were not significantly different from each other but differed significantly with treatments IT86D-610 and Zaayura. There was no significant difference existing among treatments SARI 1-4-90, Padi tuya, Songotra, IT99K-1122, Sanzi and IT07K-299-6. Table 4 shows that high number of seeds were recorded in genotypes SARI 5-5-5, SARI 1-490, Apagbaala, Padi tuya, IT07K-299-6 and Songotra respectively whereas the least was recorded in genotype Zaayura.
TABLE 4

Mean number of pods per plant and mean number of seeds per pod

\begin{tabular}{lll}
\hline Treatments & $\begin{array}{l}\text { Number of } \\
\text { pods } \\
\text { per plant }\end{array}$ & $\begin{array}{l}\text { Number } \\
\text { of seeds } \\
\text { per pod }\end{array}$ \\
\hline IT86D-610 & 2.00 & 2.78 \\
SARI 1-4-90 & 4.33 & 5.78 \\
Padi tuya & 5.33 & 5.49 \\
Zaayura & 1.33 & 1.58 \\
SARI 5-5-5 & 7.00 & 6.80 \\
Songotra & 5.00 & 5.33 \\
IT99K-1122 & 4.33 & 4.93 \\
Sanzi & 4.00 & 4.42 \\
IT07K-299-6 & 3.67 & 5.44 \\
Apagbaala & 7.00 & 5.59 \\
LSD (0.05) & 4.33 & 2.28 \\
CV (\%) & 57.80 & 27.80 \\
\hline
\end{tabular}

Galling index, root nodule formation and rootknot nematode population

The cowpea genotypes showed significantly varying levels of disease assessment $(P<0.05)$ at the final observation ( 8 WAS) at harvest (Table 5). The results show that cowpea genotypes; SARI 1-4-90, Padi tuya, Songotra, IT99K-1122 and Sanzi gave the highest galling index followed by genotypes Zaayura, IT86D-610, Apagbaala, and SARI 5-5-5 respectively whereas genotype IT07K-299-6 recorded the least root galling. Cowpea genotype SARI 5-5-5 gave the highest number of root nodules followed by cowpea genotypes; IT07K-299-6, Apagbaala, IT99K-1122, SARI 1-4-90, Padi tuya, Songotra, Sanzi and IT860-610 respectively whereas genotype Zaayura had the least root nodules. There was significant difference $(P<0.05)$ amongst the cowpea genotypes regarding the mean population of second stage juveniles (J2) recovered in $250 \mathrm{~cm}^{3}$ of soil at harvest (Table $5)$. The highest number of $\mathrm{J} 2$ was recorded in 
the Apagbaala followed by Songotra, IT860- the 10 cowpea genotypes varied significantly 610, IT99K-1122, IT07K-299-6, Zaayura, among them $(P<0.05)$. The highest RI of SARI 5-5-5, Padi tuya and Sanzi, respectively, 30.00 was recorded for Apagbaala whereas whereas genotype SARI 1-4-90 had the least nematode population. The RI recorded for

SARI 1-4-90 had the lowest RI of 19.33 (Table 5).

TABLE 5

Galling index, number of root nodules formed and second stage juvenile population per $250 \mathrm{~cm}^{3}$ of soil sample after harvest

\begin{tabular}{llllll}
\hline Genotypes & $\begin{array}{l}{ }^{a} \text { Root gall } \\
\text { Index }\end{array}$ & Root nodules & $\begin{array}{l}J 2 / 200 \mathrm{~cm}^{3} \\
\text { soil }\end{array}$ & ${ }^{b} R I$ & \\
\hline IT86D-610 & 1.67 & 22.67 & 276.7 & 27.67 & $\mathrm{SR}$ \\
SARI 1-4-90 & 2.33 & 30.67 & 193.3 & 19.33 & $\mathrm{MR}$ \\
Padi tuya & 2.33 & 27.67 & 216.7 & 21.67 & $\mathrm{MR}$ \\
Zaayura & 2.00 & 22.00 & 250.0 & 25.00 & $\mathrm{SR}$ \\
SARI 5-5-5 & 1.33 & 35.33 & 250.0 & 25.00 & $\mathrm{SR}$ \\
Songotra & 2.33 & 25.00 & 283.3 & 28.33 & $\mathrm{MR}$ \\
IT99K-1122 & 2.33 & 31.33 & 266.7 & 26.67 & $\mathrm{MR}$ \\
Sanzi & 2.33 & 25.00 & 200.0 & 20.00 & $\mathrm{MR}$ \\
IT07K-299-6 & 1.00 & 33.67 & 266.7 & 26.67 & $\mathrm{SR}$ \\
Apagbaala & 1.67 & 33.33 & 300.0 & 30.00 & $\mathrm{MR}$ \\
LSD (0.05) & 1.03 & 8.14 & 58.01 & 7.30 & \\
CV (\%) & 31.30 & 16.70 & 13.60 & 17.10 & \\
\hline
\end{tabular}

${ }^{a}$ Root gall index based on 0-5 scale $(0=$ no galls, $1=1-2$ galls, $2=3-10$ galls, $3=11-30$ galls, $4=31-100$ galls, 5 $=$ more than 100 galls) (Taylor \& Sasser, 1978).

${ }^{b} \mathrm{RI}$ : Reproduction index $=$ Final second stage juveniles $(\mathrm{J} 2)$ of $\mathrm{RKN}$ extracted from the soil/initial $\mathrm{J} 2$ in the field $\times 100$ (Taylor, 1967).

'Resistance level based on the RI where VR-Very Resistant, MR-Moderately Resistant, SR-Slightly Resistant and S-Susceptible.

\section{Discussion}

Growth characteristics of cowpea genotypes

None of the cowpea genotypes were tolerant in the present study. Tolerance is a separately measured trait that characterizes the ability of a plant to grow and yield well even when infested with nematodes (Trudgill, 1991). Growing resistant cultivars has the advantage of preventing nematode reproduction and reducing yield losses in the current crop.
Reduced functionality of roots from nematode infestation leads to water stress and nutrient deficiency, which in turn lead to poor plant growth in terms of plant height, number of leaves and reduced yield (Zwart et al., 2019). Higher height of a cowpea plant is a disadvantage in terms of lodging during heavy rains and winds, this in fact is a trait that breeders would wish reduced to avoid lodging. At 4, and 6 WAP, Padi tuya, SARI 5-5-5 and 
IT07K-299-6 increased in plant height and number of leaves. Cowpea genotype Songotra showed outstanding performance during all the growth stages. There was an increase in plant height and number of leaves at all the growth stages $(4,6$ and 8 WAP). It was observed in cowpea genotypes IT86D-610, Zaayura and Sanzi that there was a decline in plant height at 6 WAP. This is in agreement with Riches et al. (1992) who suggested that reduced growth in terms of plant height is a characteristic of nematode-infested and invaded cowpea plant. The vigour of a plant influences resistance to nematodes (Kehr, 1966). Contrary, in the current work, genotype SARI 5-5-5 had the highest plant height at 8WAP compared to genotype SARI 1-4-90 which recorded significantly low RKN population per $200 \mathrm{ml}$ soil though SARI 5-5-5 was slightly resistant whereas SARI 1-4-90 was moderately resistant to root-knot nematode attack.

\section{Yield assessment}

From the study, the highest number of pods per plant and seeds per pod were recorded in cowpea genotype SARI 5-5-5 despite being slightly resistant to RKN infestation compared to genotype SARI 1-4-90 and IT99K-1122 which were moderately resistant. However, the high buildup of nematodes in its rhizosphere could predispose subsequent crops to attack. This may be due to the quantity and size of the seeds. Low yield was recorded in Zaayura and genotype IT86D-610 as they produced a fewer number of pods and seeds. This agrees with Agrios (2005) who reported that nematode infestation in legumes could result in a total loss. The absence of galls or fewer galls on the roots of cowpea varieties may indicate their ability to inhibit the formation of feeding sites to support the reproduction of females after penetration (Williamson \& Kumar, 2006).
Root nodule formation, root galling and population of Meloidogyne spp.

Generally, root knot nematode resistance or tolerance is tested by measuring plant performance and rating symptoms, such as root galls (Sasser et al., 1984; Chakraborty et al., 2016). Because growers are interested in the yield and quality of products, this is an important criterion. However, the rate of nematode reproduction should also be determined. Gall number and the degree of galling may be used to reflect the ability of a plant to lessen or overcome the attack by the root-knot nematode (Durrant \& Dong, 2004). However, they do not indicate nematode reproduction directly. Cowpea genotypes IT07K-299-6 and SARI 5-5-5 produced high number of nodules and the lowest galling index of 1.00 and 1.33, respectively, though they confer slightly resistant (Table 5). This observation is in disagreement with Idowu (1993) that, some cowpea varieties are tolerant to nematode infestation. Nematode populations in the root region of resistant plants sometimes decline at a more rapid rate than can be explained by starvation and it is presumed that toxins of plant origin are responsible (Vargas et al., 1996). The lowest number of root nodules were recorded in cowpea genotype Zaayura with an average of 22.0 with a galling index of 2.00. Maximum galling index of 2.33 was recorded in cowpea genotypes SARI 1-4-90, Padi tuya, Songotra, IT99K-1122 and Sanzi. This is in agreement with the report by Sikora \& Fernandez (2005) that the presence of galls on the root system is a primary symptom associated with Meloidogyne infection. Karssen \& Moens (2006) reported that highly susceptible host plants allowed juveniles to enter the roots, reached maturity and produced many eggs while the resistant plants 
suppressed their development and thus, did not allow reproduction. The population of second juvenile (J2) stage of Meloidogyne recorded from the pot at harvest (Table 5) indicates that genotype SARI 1-4-90 had the lowest population density of 193.3 juveniles $/ 250 \mathrm{~cm}^{3}$ of soil. This observation is in accordance with the report by Khan (1994) that the nematode resistance in host plant was manifested by reduced rates of nematode reproduction and consequently, low nematode population densities than that of a susceptible one. This was followed by Sanzi, Padi tuya, IT860-610 and Songotra with 200.0, 216.7, 276.7, 283.3 J2 per $250 \mathrm{~cm}^{3}$ of soil respectively. There was no significant difference in the population of the Meloidogyne spp. between cowpea genotypes SARI 5-5-5 and Zaayura and IT99K-1122 and IT07K-299-6. The control treatment Apagbaala recorded the highest population density of 300.0 juveniles per $250 \mathrm{~cm}^{3}$ of soil.

The use of resistant varieties is the most economical and efficient method for the control of RKN. RI is considered a good indicator of resistance as it measures nematode establishment and reproduction in the host (Hadisoeganda \& Sasser, 1982). Based on the RI values obtained, none of the cowpea genotypes studied was immune to root-knot nematode. However, RI data showed that cowpea genotypes SARI 1-4-90, Padi tuya, Songotra, IT99K-1122, Sanzi and Apagbaala were moderately resistant (i.e. RI of $10 \leq \mathrm{RI}$ $<25$ ) whereas cowpea genotypes IT86D-610, Zaayura, SARI 5-5-5 and IT07K-299-6 were slightly resistant (i.e. RI of $25 \leq \mathrm{RI}<50$ ). This difference in the disease reactions for plants grown under the same environmental conditions may be due to inherent difference in factors controlling the ability of the cowpea genotypes to withstand the same environmental conditions and nematode infection as postulated by Williamson and Kumar (2006).

\section{Conclusion}

The study showed that cowpea genotypes SARI 1-4-90, Padi tuya, Songotra, IT99K-1122, Sanzi and Apagbaala were moderately resistant whereas cowpea genotypes IT86D-610, Zaayura, SARI 5-5-5 and IT07K-299-6 were slightly resistant. Thus, the six cowpea genotypes which were considered moderately resistant were suggested to be used as a source of resistance to RKN in future breeding works and even then farmers are advised to use additional control measures to reduce the nematode effect for optimum yield.

\section{Acknoledgement}

The authors are thankful to the Laboratory Technicians and Research Assistants of the Agronomy Department of the University for Development Studies, for assisting in the data collection.

\section{REFERENCES}

Adegbite, A. A. (2011) Assessment of yield loss of cowpea (Vigna unguiculata L.) due to rootknot nematode, Meloidogyne incognita under field conditions. Field Studies 1 (3), 79 - 85.

Adu-Dapaah, H., Afun, J. V. K., Asumadu, H., Gyasi-Boakye, S., Oti-Boateng, C. \& Padi, H. (2005) Cowpea Production Guide. Amayen Press. pp. 44.

Agbogidi, O. M. \& Egho, E. O. (2012) Evaluation of eight varieties of cowpea (Vigna unguiculata (L.) Walp) in Asaba agro-ecological environment, Delta State, Nigeria. European Journal of Sustainable Development 1 (2), 303.

Agyenim-Boateng, S., Kornahrens, M. \& Zikermann, J. (2006) Response of cowpea to 
previous poultry manure and mineral fertilizer application. Ghana Journal of Horticulture 5, 93-98.

Agrios, G. N. (2005) Plant Pathology, 5th edn. Elsevier Academic Press, Oxford, UK, 593 -599.

Chakraborty, G., Mondal, G. S., Karmakar, P., Roy, D. \& Samanta, P. (2016) Screening of some pulse germplasm for their reactions to root knot nematode, Meloidogyne incognita (Kofoid and White) Chitwood. Current Nematology 27, 137 - 142.

Collange, B., Navarrete, M., Peyre, G., Mateille, T. \& Tchamitchian, M. (2011) Root-knot nematode (Meloidogyne) management in vegetable crop production: The challenge of an agronomic system analysis. Crop Protection 30 (10), 1251 - 1262.

Durrant, W. E. \& Dong, X. (2004) Systemic acquired resistance. Annual Review of Phytopathology 42, $185-209$.

Favery, B., Quentin, M., Jaubert-Possamai, S. \& Abad, P. (2016) Gall-forming root-knot nematodes hijack key plant cellular functions to induce multinucleate and hypertrophied feeding cells. Journal of Insect Physiology 84, $60-69$.

Gbaguidi, A. A., Dansi, A., Loko, L. Y., Dansi, M. \& Sanni, A. (2013) Diversity and agronomic performances of the cowpea (Vigna unguiculata) landraces in Southern Benin. International Research Journal of Agricultural Science and Soil Science 3 (4), 121 - 133.

Gheysen, G. \& Mitchum, M. G. (2011) How nematodes manipulate plant development pathways for infection. Current Opinion in Plant Biology 14 (4), 415 - 421.

Hadisoeganda, W. \& Sasser, J. N. (1982) Resistance of tomato, bean, southern pea, and garden pea cultivars to root-knot nematodes based on host suitability. Plant Disease 66, 145 - 150 .
Hussey, R. S. \& Barker, K. R. (1973) A comparison of methods of collecting inoculum of Meloidogyne spp., including a new technique. Plant Disease Report 57, 1025 - 1028.

Idowu, A. A. (1993) Assessing the Advantage of Intercropping In Nematode Management. International Nematode News 60, 31 - 33 .

Karssen, G. \& Moens, M. (2006) Root-knot nematodes. In: Perry, R.N. and Moens, M. (eds). Plant Nematology. CABI publishing, $59-90$.

Kerh, A. H. (1966) Current status and opportunities for the control of nematodes by plant breeding. pp. 126 - 138. In Pest control by chemical, biological, genetic and physical means. (A symposium). Agricultural Research Services. USDA, ARS, $33-110$.

Khan, M. R. (1994) Nematology in developing countries; India-IMP, Region VIII. In: C. C. Carter, and J. N. Sasser, Eds. An advanced treatise on Meloidogyne 1: Biology and control. Co-Publication of Department of Plant Pathology North Carolina State University and the USAID, Raleigh, North Carolina, USA, $379-398$.

Lamovšek, J., Urek, G. \& Trdan, S. (2013) Biological control of root-knot nematodes (Meloidogyne spp.): Microbes against the pests. Acta Agriculturae Slovenica 101 (2), 263 - 275.

Lawson, L. Y. D., Abu, M., Dzomeku, I.K. \& Ndebugre, M. (2006) Effect of cowpeavegetable intercrop on weed infestation and yield of some vegetable crops. Ghana Journal of Horticulture 5, 120 - 128.

Moens, M., Perry, R. N. \& Starr, J. L. (2009) Meloidogyne species - a diverse group of novel and important plant parasites. In: R. N. Perry, M. Moens, and J. L. Starr, (eds). Root-knot nematodes. Wallingford, UK: CAB International, 1-17. 
Nicol, J. M., Turner, S. J., Coyne, D. L., Nijs, L. Den. \& Hockland, S. (2011) Current Nematode Threats to World Agriculture. http://doi. org/10.1007/978-94-007-0434-3

Riches, C. R., Hamilton, K. A. \& Parker, C. (1992) Parasitism of grain legumes by Alectra species (Scrophulariaceae). Annals of Applied Biology 121, $361-370$.

Sasser, J. N., Carter, C. \& Hartman, K. M. (1984) Standardization of Host Suitability Studies and Reporting of Resistance to Root Knot Nematodes. Coop. Pub. Department of Plant Pathology, North Carolina State University and USDA, Raleigh, North Carolina.

Sikora, R. A. \& Fernandez, E. (2005) Nematode parasites of vegetables. In: M. Luc, R.A. Sikora, \& J. Bridge, (eds.). Plant Parasitic Nematodes in Subtropical and Tropical Agriculture. CAB International, Wallingford, $319-392$.

Singh, B. B., Timko, M. P. \& Aragao, F. J. L. (2014) Advances in cowpea improvement and genomics. In Gupta, S, Nadarajan, N. and Gupta, D. S. (editors) Legumes in the Omic Era, Springer Press, New York, USA, 131 154.

Singh, S., Singh, B. \& Singh, A. P. (2015) Nematodes: A Threat to Sustainability of Agriculture. Procedia Environmental Sciences 29, 215 - 216.

Sokoto, A. L. \& Singh, A. (2008) Yield and yield components of cowpea (Vigna unguiculata L. Walp.) as influenced by Sokoto phosphate rock and placement methods in the semi-arid zone of Nigeria. Nutrient Cycling in Agrosystems $\mathbf{8 1}, 255-265$.
Surendra, K. G., Gamini, S., Bhumesh, K. V.\& Aditi, N. P. (2014) Status of root-knot nematode (Meloidogyne species) disease in vegetable crops of some districts of central plain region of Chhattisgarh State, India. African Journal of Microbiology Research 8 (16), 1663 - 1671.

Taylor, A. L. (1967) Introduction to research on plant nematology: a FAO Guide to study and control of the plant parasitic nematodes. Food and Agricultural Organization of the United Nations, Rome.

Taylor, A. \& Sasser, J. (1978) Biology, identification and control of root-knot nematodes (Meloidogyne species). pp. 111.

Trudgill, D. L. (1991) Resistance to and tolerance of plant parasitic nematodes in plants. Annual Review of Phytopathology 29, 167 - 192.

Vargas, R., Rodriguez, A. \& Acosta, N. (1996) Components of nematode suppressive activity of velvet bean, Mucuna deeringiana. Nematropica 26, 323 (Abst.).

Whitehead, A. G. \& Hemming, J. R. (1965) A comparison of some qualitative methods of extracting small vermiform nematodes from soil. Annual Applied Biology 55, 25 - 38.

Williamson, V. M. and Kumar, A. (2006) Nematode resistance in plants: The battle underground. Trends in Genetics 22, $396-403$.

Zwart, R. S., Thudi, M., Channale, S., Manchikatla, P. K., Varshney., R. K. \& Thompson, J. P. (2019) Resistance to Plant-Parasitic Nematodes in Chickpea: Current Status and Future Perspectives. Frontiers in Plant Science 10, 966. doi: 10.3389/fpls.2019.00966. 